\title{
Geological stories from the journey of mollusks fossils in Java
}

\author{
Aswan \\ Geology Department, Institut Teknologi Bandung (ITB), \\ Jl. Ganesha 10 Bandung, Indonesia (40132); email: aswan_gl@gl.itb.ac.id, +62-85314001580
}

\begin{abstract}
The journey began in the Eocene with the presence of mollusk fossil in the Nanggulan Formation (near Yogyakarta) in Central Java. Many experts believe this was the early part of the Tethys system which might still be connected to the Tethys system in Europe.
\end{abstract}

The oldest mollusk fossils type locality after Nanggulan is the Early Miocene Jonggrangan Formation in Kulon Progo near the city of Yogyakarta, which is dominated by the gastropod Haustator specimen. Molluscan paleontological studies of this type of locality reflect a restricted environment with less influence of the Tethyan system. Haustator are considered as the ancestor of the Turritellidae group, which is found mostly on Java Island, during the younger Tertiary to Quaternary Periods.

The story continued to the Middle Miocene where the Tethyan realms indication was clearly observed by the presence of some typical Tethys species such as Volema and Babylonia from Nyalindung Formation, West Java. The regional sea level rise in this epoch (around $12 \mathrm{Ma}$ ) that was indicated by the presence of Vicarya as an index fossil, which occurrence was due to land submerging to become mangroves area. The fossil then quickly become extinct when the sea level dropped back.

Copyright (C2021. FOSI. All rights reserved.

A Special Publication of abstracts and extended abstracts from the conference in honor of the retirement of Prof. Yahdi Zaim, IPU (22-23 March 2021).

DOI: $10.51835 /$ bsed.2021.47.3.361 
Late Miocene to Pliocene was like the transition period from the Tethyan realm to the Pacific realm, where the Tethyan fauna was no longer present. Only evolutional traces of the Middle Miocene mollusk fossils were observed. This continuous evolution is most clearly seen in Turritella cramatensis (late Miocene), Turritella acuticarinata (early Pliocene) and Turritella cikumpaiensis (late Pliocene) which was interpreted to have originated from Turritella angulata as their ancestors.

Earth cooling environment that happened in the late Pliocene/early Pleistocene has led the diversity and evolution of a new group of mollusks, most clearly observed from the abundance of Turritella bantamensis in the Bojong Formation, Banten. The new Turritella group has a curved whorl that different from its predecessor with an angled whorl shape.

Plio-Pleistocene tectonics event has ended the period of Java marine mollusks domination, then only freshwater mollusk fossils can be found in almost all Quaternary mollusks-bearing deposits.

Keywords: mollusks, fossil, Tertiary, Quaternary, evolution 